\title{
Corela
}

Cognition, représentation, langage

HS-19 | 2016

Le point de vue pris au mot

\section{Turning Points in Research: Systems and Theory}

\author{
György C. Kálmán
}

\section{OpenEdition}

\section{Journals}

Édition électronique

URL : http://journals.openedition.org/corela/4536

DOI : $10.4000 /$ corela.4536

ISSN : $1638-573 X$

Éditeur

Cercle linguistique du Centre et de l'Ouest - CerLICO

\section{Référence électronique}

György C. Kálmán, « Turning Points in Research: Systems and Theory », Corela [En ligne], HS-19 | 2016, mis en ligne le 08 juin 2016, consulté le 07 mai 2019. URL : http://journals.openedition.org/ corela/4536 ; DOI : 10.4000/corela.4536

Ce document a été généré automatiquement le 7 mai 2019.

\section{(a) $\odot \otimes \odot$}

Corela - cognition, représentation, langage est mis à disposition selon les termes de la licence Creative Commons Attribution - Pas d'Utilisation Commerciale - Partage dans les Mêmes Conditions 4.0 International. 


\title{
Turning Points in Research: Systems and Theory
}

\author{
György C. Kálmán
}

\section{Introduction}

1 I my early youth, one of my decisive intellectual experiences has been Gilbert Ryle's The Concept of Mind (Ryle 1949). Though I have only faint memories of the topics or the arguments, the essence of the whole book lied in the vigorous and passionate attack on a philosopher who had died long ago, a certain René Descartes - a personal and intimate fervor, as if counting on the quick and vehement reply of the late partner in the debate section of the next issue of a scholarly journal. I felt a hot commitment in this attitude, a personal concern, contradicting to all what I had hitherto thought of philosophizing (or „science” in general): I have been interested in Ryle (and in analytical philosophy, philosophy of language and all its versions and fields in general) just because I had thought it had been far from all subjectivity, personal sentiments, opinions and vague suppositions, it was dominated, instead, only by pure and cool reason, truth and sober argumentation. In this respect, it has been quite strange - and, strangely enough, sympathetic - the passionate attitude of Ryle: suggesting that scholarly thinking (at least, in philosophy or, at least, that of Ryle) was not the sterile realm of ideas but interests and wishes, commitments and distances, attractions and repulsions played part in it.

It seems then, and this is what I have realized while reading Ryle, that in certain disciplines there is no big temporal gap between the old problems and the new ones (and, it seems, philosophy is such a discipline, and so are literary studies), that is, old questions may elicit reactions pertaining to the very present. So that the history of these disciplines - or their relation to their own history - is quite different from other disciplines.

3 Just take two counter-examples. The first is a very simple one: let us place all what happened to Descartes and Ryle to the field of "real" or "strict" sciences: can we imagine someone to attack, hundreds of years later, a scholar of high reputation and authority like Descartes in philosophy, in another field of study? Would we take someone seriously 
who criticized the most important figures of the history of science, e.g., Newton or Linné, in the twentieth century, with harsh words and personal passion? Nonsense. One can only repeat the well known and now commonplace thesis of Dilthey (1910) that social sciences and natural sciences are very much different. This is just an element, and not at all the most important one, of this opposition: namely, that human and natural sciences differ in respect to their history and historicalness.

4 As another counter-example, consider the other side, treating a very actual, exciting, "hot” topic with a cool, distanced, detached, reserved tone, looking at it from a historical perspective - can one do this? Certainly, sometimes it is just our ambition - and it can be definitely annoying to give up all subjectivity, engagement or personal involvement. Just think of cases of heated critical discussions where, instead of argumentation, one of the parties just judges and contextualizes the arguments, pretending to be a bystander, an observer or historian, and not a participant.

5 This behavior is, in itself, a style of warfare, of course - changing the position, even if temporarily and seemingly, secures the illusion of invulnerability; just as the opposite step (that is, choosing, instead of a descriptive, distanced, „objective" position, the passionate, devoted, hot-tempered debate) is also a manner of war. If it is true, cannot we simply regard these versions as simple rhetorical tricks, mere verbal ploys by which we want to call the attention to our own arguments, or trying to captivate the sympathy of the reader? That is, should we take these shifts seriously, the change of positions between discussing or analyzing, participating or observing, does it have any significance, beyond rhetoric?

6 So let us turn back to the first counter-example: what I tried to show was that natural and human sciences differ also in the respect that their relation to their own history is very much different. If it is true then choosing the position itself may be part of this peculiarity. That is, it is hard to imagine that in a discourse (or debate) in the realm of natural sciences one of the participants decides to take a point of view of the history of science, or that a historian of the science decides to start arguing with the subject of his own narrative.

7 The history of science, as is known from the history of natural sciences and especially from the historical model of paradigm changes of Kuhn (1962), is a succession of closed, completed periods. An era will replace the former one by rendering it of mere historical interest: its issues are not issues of a discussion any more, it is not our interest to argue for or against any of the standpoints which were important in the past. In this respect, it ceases to be interesting - only inasmuch as the history of science means some interest. In the humanities, this is different: one could say that whatever we touch of the texts of the past, we can form a vivid, disputant, interpretive relation with them, from Plato to the present day. The situation may be somewhat more complicated, and it is an exciting question why this or that period, thinker or school of thought is regarded as something worth addressing (or regarded as addressing us).

8 So it deserves a short glance what is revived, why and by whom. Think, for example, of Positivism - who cares about it? Is it interesting? And if it is, why and for whom? There was a time, decades ago, when in university education it seemed very important to make the students understand what Positivist methods, principles and individual scholars were in order to formulate deep criticism against them, to disqualify them (and, in certain respects, evaluate and appreciate them). However, there has not been a similar ambition to re-evaluate and re-interpret New Criticism or Impressionistic Criticism - just check the 
difference between the scholarly literature devoted to them. Structuralism, again, is a chapter in the history of human sciences which has remained very long on the agenda (presumably for different reasons), and it reoccurs again and again, its history itself is rewritten from time to time.

9 To repeat the consequence, in our field cultivating „history of the sciences” is in fact not at all (or only rarely, in exceptional cases) a historical sort of study: that is, it is not an analysis of closed, completed periods but rather raising, again, older questions. Just as the example of Ryle shows, it is not the case that whatever has passed is closed forever, and our interest is only of a historical kind, but we may be engaged in it, and it is our desire to convince our audience that we have something to do with all this old stuff. Another example from another field is Freud: psychoanalysis has a history of its own, there is an enormous amount of texts dealing with the lives, cases, works and practices of Freud and his successors. However, there are, up to the present day, a number of works which feverishly criticize, more than a hundred years later, psychoanalysis in its entirety or in parts, giving new interpretations or seeking for new answers or new questions. Such a situation could not happen in the history of biology or chemistry. Moreover it can be suspected that the history of the science - in this case, that of psychoanalysis - is not just an innocent and objective description of happenings of the past (or views held long ago). Maybe not in all cases, but often we may have the impression that this „history” was born with the intention to teach a lesson for the present, or at least counting on an interest for the distances, objective account. If I am not mistaken, Pierre-Yves Raccah (2005) argues in a similar vein when he warns that ,the so called 'natural laws' should be interpreted as possible constants of the human cognitive systems, or as relating the human cognitive system to the world we observe, but not as properties of that world alone".

\section{Turning Point as a Construct}

10 Whenever we look for a turning point in the history of human sciences, we must be aware of the fact that marking off such a point, or an important event (an author, a work etc.) in our field is far from being an ever valid, impartial, objective act; naming a period (or an author, a work, a theory etc.) a turning point is, in fact, an activity by which we not only write (or re-write) the history of the human sciences but it also counts as a contribution to the scholarship of our own present. Partly indirectly, since we have in our mind a certain idea of the science, an idea of history, a notion of conceptual purity or opaqueness, etc. - and partly directly, for we would wish to call the attention to some moral, some aspect worth considering, some effective argument. Stating, for instance, that Positivism was a turning point in literary studies, we necessarily imply a sort of ideal of scholarly thinking, and we raise, again, the problem of facts - independent of the question how far it is well-founded, legitimate or, moreover, historically correct.

11 To put it in a somewhat other way, the term "turn" refers to something like saying that after a certain „event" something is not like it was before that event. These „events” are pretty difficult to discover in the history of literary, linguistic (or any other human) studies, but still we use the term rather bravely. And if we do, we must face at least two questions: the first is how we justify this change (the turn or sharp difference between before and after), and, second, why we choose just this or that special event as a turn (what this choice witnesses, what it shows of our preferences, interests, world view). 


\section{Systems Theory as a Turn}

12 If my choice is system theoretical approaches or schools (of literary studies, for instance), then (first) I must give account of why I see something interesting in this trend (if it is one trend); if it is important, then it has something to do with our present questions, either as relevant questions or relevant replies - in any case, there should be a possibility of dialogue in that school(s). And (second) all what I have said above has been formulated in terms of systems approaches, it could not have been written independent of the considerations of systemic thinking of human sciences.

13 Take the example of literary studies. They are not necessarily interested, in the first place, in what, how and why should be interpreted - more exactly: there are several rival trends in literary studies, some foregrounding just these problems (what is a text? why do we call a text literary? how is this quality recognized? what does the reader do with a literary text, and is she right?). In these trends the object of the inquiry is the literary text (its structure, for instance), and the receiver, perhaps the writer, and it is intentionally (and with a good reason) limited to the text and its interpretation, refraining from whatever is non-literary, which does not belong to the area of literature proper. Structuralism is about the structure of the text and does not wish to step out of this circle. But the trends which I label systematic here would challenge the beatific quality of this line of inquiry. It is not the case that systems theory would „surpass" Structuralism, that is, I am not implying any evolutionary process here: but it offers another perspective, and invites us to rethink old, outdated points of view which has been regarded as alien to the essence of literature.

14 I have two examples - none of these authors would call themselves proponents of the systemic approach but they can be characterized by a line of thought which leads away from Structuralism towards various trends which can be subsumed under this label. More than thirty years ago Jonathan Culler reviewed what else, what more important and interesting things could have been done than merely analyzing texts - as it had been formed, by New Criticism, an almost obligatory and exclusive practice. His essay (entitled „Beyond Interpretation") is an introductory chapter of a book (Culler 1981), so it just quickly flashes some of the trends which might have been promising and surpassing text analysis - from the social determination of literature (represented by the Marxist Jameson) through the deconstructive potential within the texts (Derrida, de Man, Hillis Miller) to the schools concentrating on the multiplicity of texts, their interconnections, histories, genres and intertextual connections. That is, extrapolating the writing of Culler, one could step out of the narrow place of text / reader, towards systems. The other author is Siegfried J. Schmidt (Schmidt 1991) who (himself and the members of his school entitled Empirical Literary Studies) reviewed the whole system where literature works with a mathematical rigor (where literary system is just a subsystem of the whole system of society complying to special rules corresponding to it); on the other hand, strangely enough, they celebrate non-systematic, chaotic, free and uncontrolled behavior whenever it comes to interpretation (the central saint of the Structuralist schools). That is, this systems theoretical approach gives way to "literary erotic", since interpretation itself challenges all rules, and it cannot be described according to strict rules.

15 As of the late sixties, very different but in their ambitions and certain principles rather similar schools and trends appeared on the scene. One could perhaps try to tell this story 
as that of the decay of Structuralism, its decomposition - still, the situation is much more complex.

First, there were trends which the historians of Structuralism were happy to classify as parts of Structuralism - however, they became, quite easily, parts of the systems theoretical approaches. This can be another example that writing the history of science is not an objective and innocent activity, but through its classification (ignoring or incorporating) the possible questions it in fact shapes this history. When Todorov discovered Russian Formalism for the French Structuralism (Todorov 1965), and posited a continuity between the two, it amounted to an interpretation of the theoreticians (who could of course be interpreted in several other ways). If Éjxenbaum and Tinjanov became parts of the great Structuralist canon, from the sixties, there may come a reinterpretation (which in fact did come) to foreground their systems theoretical characteristics.

Second, some trends which can be connected to the systems theoretical schools had no relation whatsoever with Structuralism - they did not grow out of Structuralism, either are they its negations or decomposition products. One may speculate a lot on the connection between Structuralism and Bourdieu, Schmidt or Luhmann (either personally, or institutionally, or in their principles) but what is certain is that neither of them is a typical renegade or Oedipal figure. Of course, these schools have a lot to thank to Structuralism (as in the twentieth century it was inevitable to reflect on it, either as opposing or supporting it).

Third, there are trends opposing to Structuralism (or passing by it, but in their principles could have been opponents), but without any connection to systems theoretical studies. Reception aesthetics or the new Hermeneutics (the first is referred to by Culler) are in several respects anti-Structuralist trends, however, they do not have too much to do with systematic approaches. So a simple, linear narrative without several subplots cannot be formed - and this is the moral of my three points above: however tempting it could be, the story of "the decay of Structuralism" cannot be written.

19 So what are the trends which could be regarded as turning points, and what are the characteristics of this turn? The New Paradigm which Schmidt has heralded seems to come to a dead end, Empirical Literary Studies have been covered, contrary to the founders' intentions, by minute empirical case studies of psychology, sociology, reading research etc., and the theoretical foundation does seem to offer enough armory for the historical, textual or intertextual work. Strangely enough, the journal Poetics which used to be the periodical of the school turned towards the sociology of Bourdieu (and there has always been a contact between the French scholar and the German trend). There has been another initiative for a school, the Polysystem Theory of the excellent Israeli scholar, proponent and pioneer of the trend, Itamar Even-Zohar (1990). However, this seems to be somewhat gone out of breath: in a way, it contributed to its own problems through turning to the whole field of culture where literature is but a minor, negligible sub-field and receives little attention. Quite differentase of Bourdieu who has not been interested in the phenomenon of literature for a long time, only inasmuch as it was one of the symbolic goods - then, in his fantastic book on Flaubert (Bourdieu 1992), he offers a lot of lessons to learn, methodological as well as historical, for the student of literature, language, sociology, history, all what Bourdieu says elsewhere on culture and society is also worth considering.

The systemic approach to (or systems theory of) literature (or humanities in general) is, then, not in fact ready, completed, it could and should be put together from these very 
precious spare parts (and here I mention Luhmann again who wishes to describe the whole society in a systems theoretical way, and Habermas who treats the interconnection of communication and society in an extremely exciting way). The common element, in my opinion, is perhaps that such an inquiry would posit the process of producing, mediating and consuming texts within the structure and history of society; it would contemplate texts as operating in a given system which has its own participants, agents having different functions, roles, which can be (according to interests or constraints) changed, from time to time. It is such a change in function when a critic turns into a historian or a historian a disputant, a change referred to in my introduction. These systems are interwoven by subordinations and oppressions, power fights, interests and attractions, just as anything working in the society; these relations will then influence on the interpretations of texts (literary or other), how they are received or talked about, under what circumstances. And this is as important factor of understanding texts as the description of their inherent structure. Or, to put it even more sharply, we would not care about the structure of the texts, were there no certain social and historical determinations forcing us to do so. Something like this could constitute the core element of a systems approach, followed by a number of logical and historical rules, observations and data.

\section{Conclusion: the Actuality of Systemic Research}

21 In conclusion, if I said that regarding something as a turning point is not so much a proposition of the turning point itself but rather refers to those who pronounce this sentence, then why I consider this trend, even if it is not a complete one, as a very important one? In what does its interesting nature, linking it to the present, lie, which would justify its outstanding position? In my view, just because it does not seem to be too fashionable, it is not in the course of forming, not in motion, it is, in several respects, came to a stand, stopped, intermittent - there is a possibility, potentiality in it, a promise of work. As I see, all what has been started some thirty years ago will give us tasks even today.

Just take some very concrete examples, pertaining to our present. How and who form literary historical thinking today? Through what channels will the ideological influence of the power is realized on the shaping of literary life, education, market? How did it look like earlier? What historical continuity can we find in certain interpretations, how and by whom are they bequeathed, and what about the position of non-canonic texts in the system? Questions like these could be enumerated endlessly, and they are often treated and replied - but there may be a demand to build up the system of the systemic approaches in a systematic way in the scholarly community. Today, I see much more potential, relevant to a wider range of the scholarly field, and to several field of the human sciences, than in analyzing the structure of the texts or the characteristics of reception or their history.

Since what I have said is about meanings (though mostly meanings of literary texts), let me finish with quoting a part of Raccah's conclusion:

Meaning in natural languages can be the object of an empirical science, if it is considered as the constraints, invariant across utterances, under which the interpretation is built by the hearers, keeping in mind that interpretations are only 
indirectly observable and that, of course, constraints on them require even more theoretical work in order to be indirectly observed ${ }^{1}$. (Raccah 2005) is a tempting ad fruitful act.

\section{BIBLIOGRAPHIE}

Bourdieu Pierre, Les règles de l'art. Genèse et structure du champ littéraire, Paris, Seuil, 1992.

Culler Jonathan, „Beyond Interpretation”, in Culler Jonathan, The Pursuit of Signs: Semiotics, Literature, Deconstruction, London, Routledge and Kegan Paul, 1981, pp. 3-17.

Dilthey Wilhelm, Der Aufbau der geschichtlichen Welt in den Geisteswissenschaften. Frankfurt, Suhrkamp Verlag, [1910] 1981.

Even-Zohar Itamar, „Polysystem Theory”, Poetics Today vol. 11, nº 1, 1990, pp. 9-26.

Kuhn Thomas Samuel, The Structure of Scientific Revolutions, Chicago, University of Chicago Press, 1962.

Ryle Gilbert, The Concept of Mind, Chicago, University of Chicago Press, 1949.

Raccah, Pierre-Yves, "What is an empirical theory of linguistic meaning a theory of?", in Zygmunt Frajzyngier, David Rood and Adam Hodges (eds.), Diversity and Language Theories, Amsterdam, Benjamins, 2005, pp. 51-80. On-line http://linguistes.fr/public/Raccah/ Liste_publications.html.

Schmidt Siegfried J., Grundriss der Empirischen Literaturwissenschaft, Frankfurt, Suhrkamp, 1991.

Todorov Tzvetan (éd.), Théorie de la littérature, textes des formalistes russes, Paris, Seuil, 1965.

\section{NOTES}

1. Emphasis mine.

\section{RÉSUMÉS}

Dans certaines disciplines, il n'y a pas de grand écart temporel entre les problèmes anciens et nouveaux: les vieilles questions peuvent provoquer des réactions qui rentrent au présent. La différence principale entre les sciences de la nature et les sciences humaines réside dans la caractéristique de la relation de chacune avec sa propre histoire. Cultiver «l'histoire des 
sciences» dans le domaine des sciences humaines ne signifie pas du tout l'étude historique ou l'analyse des périodes historiques passées, mais consiste dans la capacité de reformuler les vieilles questions. Marquer un point tournant est loin d'être un acte impartial ou bien objectif à l'ambition d'être toujours valide. La désignation d'une période historique ou d'un auteur ou bien d'une théorie (etc.) - en tant qu'événement qui marque une orientation nouvelle ou un changement important - n'est pas de décrire (ou réécrire) tout simplement l'histoire des sciences humaines, mais de contribuer à un niveau général à l'essor de la science de notre propre présent. Quand on marque un tournant, un moment ou un événement à partir duquel le cours des choses peut changer de direction, on évoque toujours ceux qui ont proposé ce changement. Dans cette communication je propose de considérer les approches des écoles et/ou des systèmes théoriques comme tournants, et je pars de l'hypothèse que l'approche systémique n'est guère obsolète. L'approche systémique ne représente pas donc un moment de l'histoire de la désintégration ou de la chute du structuralisme, mais cette approche se distingue des autres par sa façon de pouvoir mettre ensemble des différentes parties analysées dans la perspective de cette démarche. Comment le processus de production, de consommation et de la médiation de textes peut générer du sens au sein de la structure de la société et de l'histoire? Voilà la vraie question. Nous nous demandons : dans quel système, dans quel contexte les textes littéraires sont influencés par ses propres participants et ses agents ayant des fonctions et des rôles différents.

In certain disciplines there is no big temporal gap between the old problems and the new ones: old questions may elicit reactions pertaining to the very present. Natural and human sciences differ in the respect that their relation to their own history is different. In the humanities, cultivating "history of the sciences” is in fact not at all a historical study: that is, it is not an analysis of closed, completed periods but rather raising, again, older questions. Marking off a turning point here is far from being an ever valid, impartial, objective act; naming a period (or an author, a work, a theory etc.) a turning point is, in fact, an activity by which we not only write (or re-write) the history of the human sciences but it also counts as a contribution to the scholarship of our own present; regarding something as a turning point is not so much a proposition of the turning point itself but rather refers to those who pronounce this sentence. I regard system theoretical approaches or schools as such a turning point and argue that it is not a story of the decay of Structuralism, its decomposition: the systemic approach to (or systems theory of) literature (or humanities in general) is, then, not in fact ready, completed, it could and should be put together from very precious spare parts; such an inquiry would posit the process of producing, mediating and consuming texts within the structure and history of society; it would contemplate texts as operating in a given system which has its own participants, agents having different functions, roles.

\section{INDEX}

Mots-clés : histoire des sciences humaines; objectivité; points tournants; théories de système; structuralisme; théorie de la littérature

Keywords : history of human sciences; turning points; objectivity; systems theory; structuralism; literary theory; 